\title{
The Downfall of the Utopias. Pier Paolo Pasolini's Modernist Heresies
}

Norbert M. Schmitz

\section{Preface}

At the end of Luis Buñuel and Salvador Dali's L'Âge d'Or of 1930, we see, one after the other, the four main characters of the Marquis de Sade's incomplete episodic novel Les I2o Journées de Sodome ou L'École du Libertinage leave the site of the »most terrible of all orgies $\aleph^{\mathrm{I}}$ in the Chateau de Sellinay through the gate to the outside on their way back to Paris. At the head is the lord of the game, so sensual and »criminal, $\ll^{2}$ the Duc de Blangis. Much as the novel, which remains controversial to this day, became the epitome of obscenity and blasphemy, the young taboo-breaking surrealists Buñuel and Dali carry this further by staging the leader of the crimes as Jesus of Nazarene. After the masters of the »sadistic " game have crossed the castle drawbridge, a young blood-spattered girl appears and immediately falls to the ground. Jesus turns around with a gentle gaze, helps the ravished woman to her feet, and guides her back into the palace. When the door closes again, one can hear a brief, indefinable cry, a cross between lust and pain, after which Jesus emerges again, alone, with a mournful expression on his face. The scene and the film end with a close-up of a tilted cross.

While the two surrealists' first film, made the year before, Un Cbien Andalou, failed to cause a scandal, much to the chagrin of Breton's circle, this film, rich in anti-Catholic heresy, began attracting attention soon after its premiere in Studio 28 in Paris. On December 3, 1930, right-wing extremists of the »Action française « interrupted a performance of the film and demolished the cinema, along with some of the Surrealist paintings exhibited there. The ban on the film wasn't lifted until i98I. 
From the Church's point of view, this avant-garde film certainly embodied one of the most extreme forms of blasphemy through art, namely the presentation of the Lord Himself in the throes of lust. The work of Buñuel, a Spaniard who repeatedly »processed « his own Catholic upbringing in films such as Nazarin, Viridiana, and La Voie Lactée (in English The Milky Way), highlights the pleasure that the aesthetics of the avant-garde movements in $20^{\text {th }}$-century art took in the heretical act. ${ }^{3}$ By systematically breaking the taboos of the traditions of church and state as well as the idealistic ideologies of the bourgeoisie, art attained its freedom and in the process became the catalyst of social emancipation. Today, provocations of this kind tend to be more amusing and can quickly seem out of date, in other words, unmodern in a literal sense. The heretical gesture - for Buñuel, closely tied to the Church, which still had the greatest say in his native country - is beside the point, now that the culture has long since separated itself from its religious background and heresy has become a gesture of modernity as such, one that is often heroically idealized. At any rate, the traditional clerical institutions lost their power to unite people as the target of protest long ago. Subsequently, radical modernism in art recognized no boundaries to its freedom, from the child pornography of a Hans Balthus to the excesses of the Viennese Actionist Otto Mühl. ${ }^{4}$ The Church, at any rate, is no longer the »mother of the arts, « not even ex negativo. Hence, when we talk about heresy and blasphemy, and about obscenity in art at the beginning of the new millennium, it's generally in metaphoric terms only, in other words, in the context of expectations on the part of general humanity concerning questions of gender and sexuality. The canon of potential dogmatism that can still be slandered is better described by the term "political cor- 
rectness « than by the Church's teachings. All other cases, for instance the potential censorship in post-Communist Poland under the aegis of Pope Saint John Paul II, seem at best like the rearguard action of long-since faded claims to power. ${ }^{5}$

In this situation, the pathos with which the public intellectual and avantgardist Pier Paolo Pasolini investigated, over a period spanning decades, questions of religious traditions that were apparently no longer part of contemporary life, must seem odd, although blasphemy was placed side by side with the invocation of the holy. ${ }^{6} \mathrm{H}$ is a mbivalences regarding mythology, religious faith, and enlightenment were already confusing to his contemporaries, given the dominant discourse of enlightenment in the arts and the spurts in the modernization of cultural life from Europe to America. Despite all the public attention and artistic success, the poet, essayist, and filmmaker provoked the very front of the left-wing enlightenment project that he himself felt a part of.

\section{True-Life Heresy}

Empirismo Eretico, ${ }^{7}$ (Heretical Empiricism), ${ }^{8}$ is the title of one of the collections of texts by the writer and filmmaker Pasolini. The subject here is heresy, a »heresy taken from life, ${ }^{9}$ in other words, one that obviously arises out of the concrete empirical world and not the dogmas of divine and earthly theology or philosophy. What prompted the avant-gardist and, in the sense of his role model Arthur Rimbaud, so »utterly modern « a poet to use such a metaphor, one that is possibly pre-modern? ${ }^{10}$ Why was and is Pasolini's earthly materialism so disgraceful to the Church, and what Church is being slandered here? ${ }^{\text {II }}$ 
At the very least, Pasolini's cinematic works - and this is the author's thesis can be described as heresy nearly across the board. This essay, however, limits itself to four films as examples that provide an ideal overview of his work and the many winding, if not paradoxical movements that occupied the artist's political and aesthetic thinking. This selection comprises his adaptation of the Gospel according to St. Matthew, his interpretation of the folktales of the Fioretti di San Francesco, Uccellacci/Uccellini, his staging of the erotic tales in One Thousand and One Nights, and finally another screen adaptation of literature, this one quite free, of the I20 Days of Sodom by the Marquis de Sade, known by his devotees as »the Divine Marquis.« The titles, which could easily be augmented by other films by Pasolini, already indicate a progression from the sacred to the profane, from myth to modernism ${ }^{12}$ — the winding path of a »hérésie moderne.«

\section{Holiness and Myth}

In 1964, when Pasolini, the left-wing agent provocateur of the Italian art establishment, who was already widely known for his poetic, political, and publishing output, presented a nearly verbatim film version of the first gospel, Il Vangelo Secondo Matteo, he dedicated this film to the »benevolent, cheerful, affable figure of Johannes XIII«(Fig. I). ${ }^{13}$ And yet: no other film of Pasolini's — except, perhaps, his last, Salò, the discussion of which came to an abrupt end due to a performance ban — has provoked as many controversial opinions as Il Vangelo Secondo Matteo. At the premiere at the Mostra in Venice, even before the film was screened, Italian fascists rioted against the anticipated »defilement of a 
source of the Christian Occident « at the hands of an atheist Marxist; French critics considered the film to be an »irresponsible betrayal and aestheticism, " a »dubious analogy between Lenin and Christ; « and while liberal critics and leftwing theologians in the Federal Republic of Germany praised the film, some as »the best of all failed Jesus films« and some as »a piece [...] for the absolution of us all $\ll$ and defended it, critics presenting themselves as left-wing or Marxist accused Il Vangelo Secondo Matteo of being a »conformist film « that didn't »break radically enough with the Bible exegesis, «thus »trivializing Christian ideology« and resulting in a »questionable interpretation of Christianity« and a film that »is not Marxist. « ${ }^{\mathrm{I} 4}$ Later (1968), Pasolini conceded that some of the criticism was correct: »It is a violently contradictory film, profoundly ambiguous and disconcerting, particularly the figure of Christ - at times he is almost embarrassing, as well as being enigmatic. There are some horrible moments I'm ashamed of, which are almost Counter-Reformation Baroque, repellent — the miracles. The miracles of the loaves and the fishes and Christ walking on the water are disgusting pietism. The jump from this kind of holy picture scenes to the passionate violence of his politics and his preaching is so great that the Christ figure in the film is bound to produce a strong sense of unease in an audience. Catholics come out of the film a bit shaken up feeling that I have made Christ bad. He is not bad in fact, he is just full of contradictions. But while the contradictions in the text are contradictions of content, of meaning, passion, faith, religion, the contradictions in my film are more existential and therefore more disquieting. « ${ }^{\mathrm{IS}}$

What is remarkable, however, is that it's only Pasolini who thinks in religious categories, in other words, who takes Jesus' holiness seriously, while his 

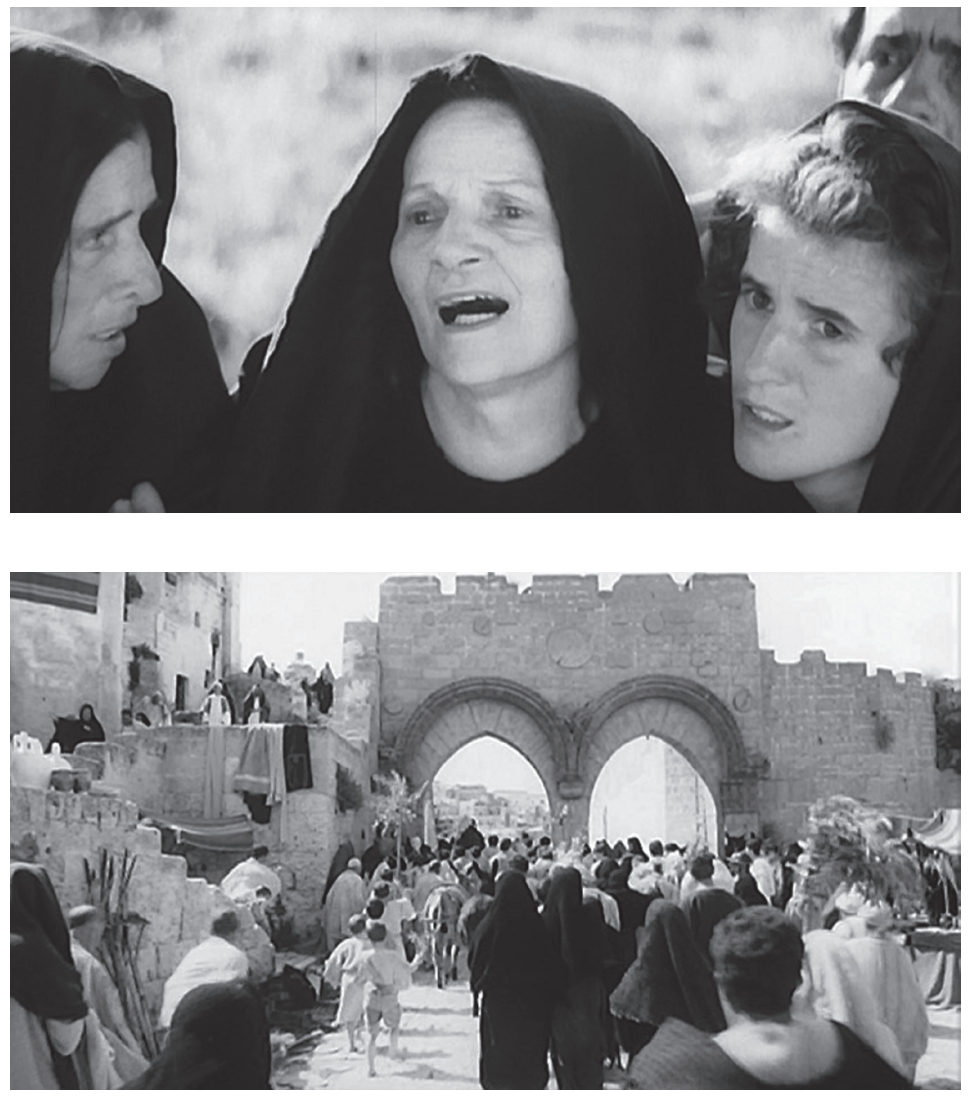

[FIG. 1]

Pier Paolo Pasolini (dir.):

Crucifixion scene with

Pasolini's mother, in Il vangelo secondo matteo, 1964

[FIG. 2]

Pier Paolo Pasolini (dir.): Image of an ancient city geography, Entry into Jerusalem, in Il vangelo secondo matteo, 1964 
various critics tend to address either the social status of the institution of the Church, the question of plausibility in the sense of an enlightened, liberal Christianity or a Marxist interpretation of history — anything but the appropriateness of using this sacred material. For even though he was an atheist, Pasolini wasn't interested in slandering God: ${ }^{16}{ }$ I would have produced a positivist or a Marxist reconstruction at most, and thus at best a life which could have been the life of any one of the five or six thousand saints that were preaching at that time in Palestine. But I did not want to do this, because I am not interested in de-consecrating: this is a fashion I hate, it is petit bourgeois. I want to re-consecrate things as much as possible, I want to re-mythicize them. ${ }^{17}$

The film, which was highly successful and which predominated in Catholic media efforts and Easter TV programming for many years, also in (West) Germany, is characterized by an almost naively direct approach to the biblical story, particularly the miracles, a view Pasolini intended to portray the savior's story from the eyes of simple peasants. It is both a passion play with few cinematographic attributes and a literal filming of literature; its precision is based less on a historical reconstruction than on the veracity of the religious tradition. It's recorded that during the filming, the free-spirited Pasolini consulted a church advisor, who saw to it that no transgressions against traditional conventions of representation entered into the work and that the rules of decorum in the Catholic pictorial tradition were followed to the letter. ${ }^{18}$ And yet, the film portrayed a revolutionary Jesus far from the image of the sweet blond figure of Nazarene, presenting the Galilean evangelist as a revolutionary with all the ruthlessness of his moral appeal. Pasolini had originally planned to shoot the film in the »Holy Land, « but a visit to Palestine showed him that in today's 
Israel, the type of archaic peasant culture in which he wished to set his gospel had long since given way to modernization. ${ }^{19}$ Instead, he found the imagined archaic culture in his own country, intact and hence empirical, in Basilicata, deep in the Mezzogiorno, a region still steeped in the time before the history of modern Italy, in which the legends of Christianity still possessed a "peasant reality.« The topographical location, even at that time a utopos, became a spiritual one that allowed the artist, marked as he was by modernist subjectivism, an immediacy from a much older time: »The gospel presented me with the following problem: I couldn't narrate it like a classical story, because I don't believe I'm an atheist. [...] For this reason, in order to narrate the gospel, I had to immerse myself in the soul of a believer. That is indirect free speech (>le discours indirect libre $<$ : ${ }^{2 \circ}$ on the one hand, the plot is seen through my own eyes, and on the other through the eyes of a believer. ${ }^{21}$ The ostensibly »plain « perspective is, however, brought to expression through an exposed artistic form. The veristic camera of the early sixties, its rough cut occasionally reminiscent of the »direct cinema « of a Richard Leacock, seems to bring this »prehistoric « culture to life in the authentic medium of film..$^{22}$ The film embodies a stylistic paradox in that, in contrast to the »arte povera « of its mise-en-scène, it is elevated through the music and the many visual compositions and abundance of Christian music and iconography. The entire spectrum of Western culture is present, ranging from a mournful blues song to Bach's St. Matthew Passion, from the garments of the early Renaissance to realistic painting of the $19^{\text {th }}$ century. ${ }^{23}$ Although the painstaking, largely verbatim adaptation from literature comes across as documentary, Pasolini does without historical accuracy in the architecture, the scientific reconstruction of the Temple, and the 


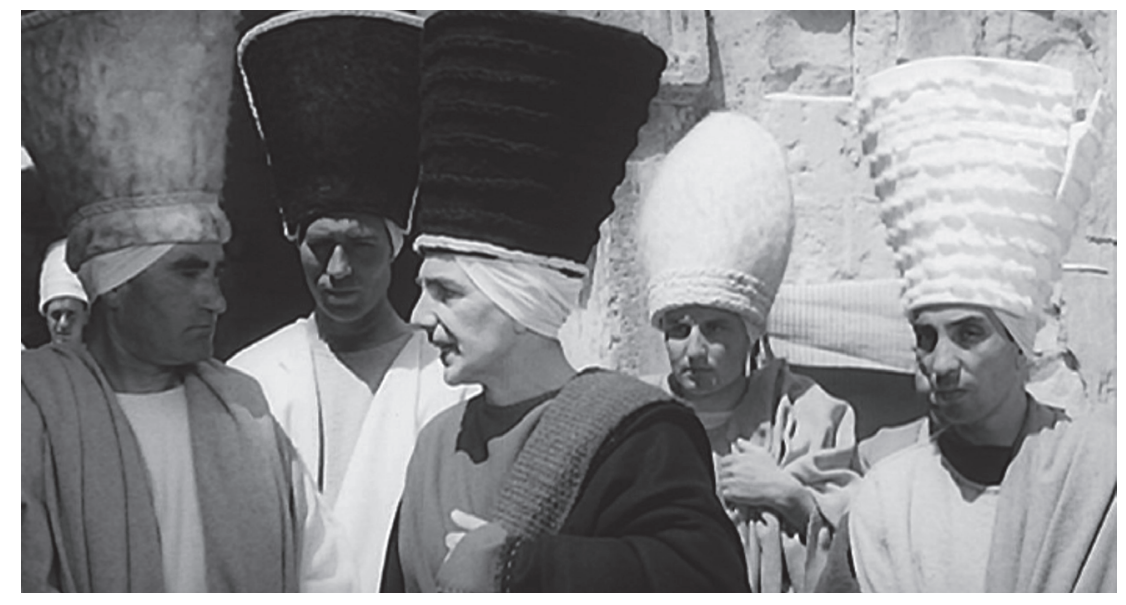

[FIG. 3]

Pier Paolo Pasolini (dir.): Piero della Francesca's Sadducees and Pharisees, in Il vangelo secondo matteo, 1964

like, and replaces these with the »aura of the medieval village of Matera. At the same time, in the faces of the Sadducees and Pharisees, we recognize the figures in Piero della Francesca's paintings. His film is anything but a cinematic exploration of the life of Jesus (Fig. 3). Why, then, does Pasolini, a well-known, self-described communist and homosexual, paint this portrait so piously, instead of presenting the key myth of Christianity against the grain of clerical interpretation, at least to a degree? Beyond this, the film has none of that neoreligious idealization that we know from many works of modern art ranging from the neo-Catholicism of the Pont-Aven School to the neo-mysticism of an esoteric avant-garde à la Kandinsky. ${ }^{24}$ Pasolini's Jesus is earthly, as concrete and materialistic as peasant folk. And it's not the director's first Passion narrative. His pimp tales in Accattone and Mamma Roma could be understood as such, for instance when the liturgical music typologically ascribes the 
miserable life of the protagonists to the Lord's suffering, and Franco Citti finally lies on his deathbed in the radical foreshortening of Mantegna's Cristo Morto. The film remains ambivalent, because on the one hand equating the brutal pimp with suffering Jesus can be considered heretical, in an attitude Pasolini found to be bourgeois, while at the same time it conjures up the mystique of the divine in day-to-day life in opposition to the rational mindset of the Enlightenment.

Appropriating historical forms and narrations into clerical art, especially in the industry of mass communication, is not rare, of course. But it is, entirely in the tradition of $»$ propaganda fide, ${ }^{25}$ almost exclusively functional, with the original claim to meaning no longer playing a role. This becomes particularly evident when the biblical narratives themselves become the stuff of entertainment and are spiced with all the ingredients of sex and crime, as in films like Cecille B. DeMille's The Ten Commandments of 1956, William Wyler's Ben Hur of 1959, and, in 20I4, in Darren Aronofsky's Noab. ${ }^{26}$ It's their success, however, that's a sign of loss, for the market laws of industrial image production prohibit linking the product to concrete religious experience. Pasolini, however, distances himself from this type of »industrial blasphemy« when he takes the Christian legend as a factum brutum of the divine truly seriously in content and form.

In complete contrast to this, at the same time that the Catholic religion began to soften its distance to modernism, in a concrete sense - and this is crucial to the »scandal « Pasolini represented — it was no longer a matter of provoking the categorical orthodoxy in the sense of a tradition overcome, but the truce that these overcome religious powers had long since reached with the industrial bourgeois culture now prevailing. This can be demonstrated particular- 
ly clearly in art, for the scandals of the Secessionists did not aim to provoke a rigid, premodern, and completely orthodox, literal religious art that asserted its claim to legitimacy in its hallowed traditions. The only thing left was a compromise, now commonplace, between traditionalist systems of value such as the Catholic faith and the everyday utopia of the industrial functional society of the bourgeoisie, as described by Luhmann. From historical painting with its photographic and ideal-realistic convention to the Hollywood kitsch mentioned above, the religious work of art triumphed »in the age of mechanical reproduction.« All substantialistic justification in faith was now replaced by pure functionality in the consumerist society. Heresy, then, does not consist in deviation, but in affirmation, in taking orthodoxy and its myths seriously. That is the real heresy of the heretic.

\section{»The Dream of a Cause: « Politics ${ }^{27}$}

The stylization of the divine that characterizes Pasolini's St. Matthew film can also be found in his invocation of another one of his religious myths, communism. On the other hand, in Uccellacci/Uccellini (The Hawks and the Sparrows, 1965), literally »ugly birds, little birds, « he picks up on a classic Christian legend, that of the »Little Flowers of St. Francis, « roughly the folkloric counterpart to Buenaventura's official hagiography in which he quotes a classic of Catholic Italian postwar cinema, Roberto Rossellini's Francesco, Giullare di Dio (The Flowers of St. Francis) of 1949, the hopeful year of neo-Realism. Following a short introduction of the protagonists, Pasolini has the vagabond duo, played 

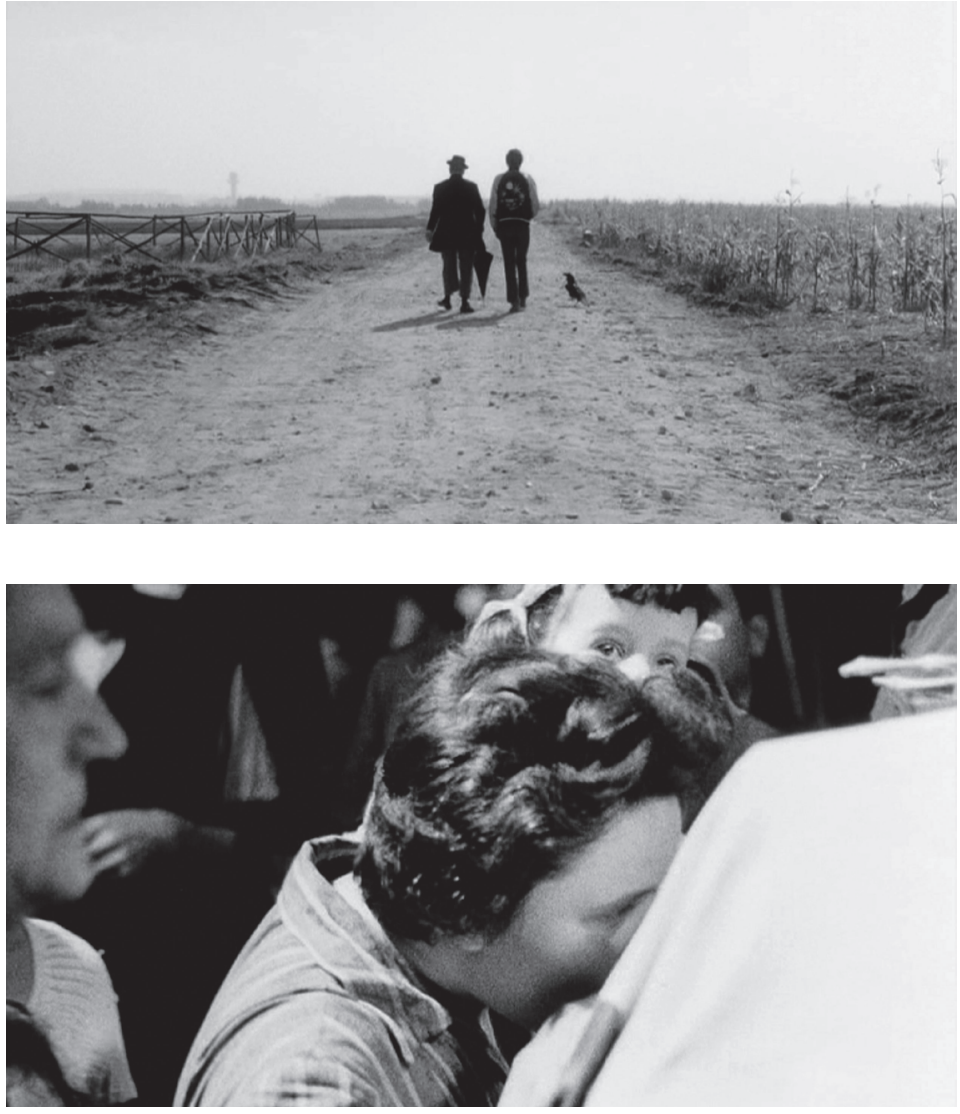

[FIG. 4]

Pier Paolo Pasolini (dir.): Totò and Ninetto as vagabonds with the raven as the author, in Uccellacci/Uccellini, 1965

[FIG. 5]

Pier Paolo Pasolini (dir.): The sholy ceremony< of Togliatti's funeral, in Uccellacci/Uccellini, 1965 
by the famous comedian Totò and Pasolini's intimate friend Ninetto Davoli, appear as Franciscan monks of the earliest days. At first, however, the order's founder forgets the two simple monks when he sends his followers out into the world to preach the new teachings. When the two, much to their surprise, are left behind, the great saint has no better idea than to instruct them to preach the good news to the birds, too. Using their childlike, naïve intuition, they initially succeed with their difficult task and actually talk to the birds, until they realize that the falcons, despite their happiness at the Lord's words, continue to hunt sparrows. Even in the realm of the birds, class relations override Christian morals. Pasolini translates this constellation into the present day when the protagonists, two Chaplin-like vagabonds, go through all kinds of adventures in which, far from any leftist glorification of the oppressed class, they become perpetrators as often as victims (Fig. 4). And right in the middle of this modern picaresque novel, Pasolini inserts documentary material from the funeral of Togliatti, the head of the Italian Communist Party, and the two heroes become its essentially inattentive onlookers. The selected images of collective grief are characterized by the religious emphasis of a ritual of veneration, performed with Mediterranean fervor that is normally reserved for saints (Fig. 5). Togliatti becomes a religious symbol and a part of the Passion iconography, with which the director, who was expelled from this same party, becomes united in what comes close to a cinematographic ritual as a kind of unio mystica. Most of all, according to Hans Ulrich Reck, the found footage of this "perhaps last authentic communist manifestation $\ll^{28}$ sacralizes the occurrence and lends it the authenticity of an encounter with a mythical ur-communism much closer to Christianity than any enlightened Marxist reflection. In the film, however, Pasolini counters the sa- 
crality reminiscent of his Gospel According to St. Matthew in several ways: through confrontations between the lofty Francis and the vagabonds' profanity, between the evocation of a truth-producing communist utopia and the minor and often amusing crimes of the hero Totò, and between the pair's comic nature and the intellectualism of the talking raven accompanying the two heroes. It's precisely this raven that is Pasolini's mouthpiece in the film when he repeatedly inundates Ninetto and Totò with his intellectual commentaries derived entirely from the new-leftist theory of the time. In the end, the intellectual is eaten by the very sub-proletariat in which the young Pasolini once placed all his hopes.

Thus Pasolini simultaneously invokes and deconstructs his own »communist myth.«To his mind, what destroyed this myth was the model of progress that the modern capitalist, consumerist society represented. Reason alone is not enough to break apart the compulsive character of this new totalitarianism; at the very least, since the days reason identified the »anthropological shift, « in other words, the conflation of repression and instrumentally rational order in the modern mass societies, it has become perverted into an instrument of the hegemony. ${ }^{29}$ »Such a >qualitative jump< therefore concerns both fascists and anti-fascists: it is, in fact, the passage of a culture made up of illiterates (the people) and of ragged humanists (the middle class) from an archaic cultural organization to a modern organization of >mass culture.< It's precisely in this >unification < that cultural identity and the possibility of resistance are irrevocably lost in favor of a general hedonism. ${ }^{30}$ This hegemony is a total one to the extent that it not only encompasses intellectual consciousness, but also eats into the body's language itself. For this reason, Pasolini cannot compromise on the prevailing conditions either with the established powers or the 
leftist opposition, because it would always require admitting to the banality of the real. To Pasolini's mind, communism, similarly to the Church, has also become bourgeois, so bourgeois that it can only be revered in mythical garb and as an image of mourning. Communism, here, is indeed a religion — albeit a dying one - a people's legend that stands no less in opposition to the status quo than its Christian counterpart. ${ }^{31}$ The two are preserved only in the films' »aesthetic shrine." Yet in Italy, too, with the »historic compromise « between Berlinguer's PCI and the Democratia Christiana, the left had found its place in bourgeois life. The »dream of a cause as a social utopia could only be conserved by artistic means.

Disappointment transforms into a new form of heresy that can be increased if not one, but several orthodoxies are worshipped in opposition to facts and »celebrated « at the same time. The »bourgeois « question of mediation between these is not even posed. Pasolini is Catholic, communist, decadent, homosexual - and all with equal enthusiasm. He demands global emancipation and the preservation of archaic cultures at the same time. ${ }^{32}$ The leftist and communist can seem conservative, against enlightenment. He invokes the motherland, and wants all motherlands simultaneously. Yet all of these »faiths, « as purely and »innocently« as they might have been articulated, provided no way out for him. While he always provoked a clear, enlightened discourse by »celebrating « its opposite - all the sacralities of a pre-rational myth — he was never at home in any one of these myths, especially when the idealized sites of resistance disappear. Thus, for Pasolini there was only one last sensuous means of maintaining his hopes. It was only in the mutual desire between bodies that Pasolini, who as a homosexual had personally experienced the rejection of the Other, believed he could find resistance to the omnipotence of 
an instrumental rationality he found to be nightmarish..$^{33}$ And this »evidence of the bodily« is also the core of his film aesthetics of a »cinema of poetry.« ${ }^{34}$

\section{The Innocence of Bodies}

Just how futile this project was can be seen in the constant flight in which Pasolini sought to conjure one cultural ideal after the next as a place of refuge from the postwar mass consumerist culture and then, disappointed, abandoned just as quickly. During these years, however, the relationship between erotic discourse and society had changed fundamentally. ${ }^{35}$ While in the art of the fin de siècle, for instance the French Décadence that Pasolini so revered, the demand for free sexuality in opposition to the prevailing bourgeois morals was still a provocative act, at the latest in the postwar era; even in backward Italy, the system combined forces with the libertinage of the postwar era. When compared with the euphoric expectations placed on sexual emancipation, it became an ordinary ware in the real-life everyday pornography of modern Italy. To Pasolini's mind, contemporary libertinage wasn't an indication of revolt, but proof of a general agreement with the status quo. Its hymn of sexuality balked against its actual fulfillment, while its concrete realization was subordinated to the purity of a poetic idea. For this reason, desperate and notwithstanding all contradictions, he always continued his search wherever, in one way or another, the system of cultural values, which was always an artistic one, had not yet become entirely subjected to the forces of uniform mass culture. He was no less »cruel« than the poets of the Décadence when, in spite 
of his communist obligation to enlightenment, he was ready to pay homage to even the most repressive of cultures as vestiges of a more original state, only to turn away once again in disappointment when the process of globalization absorbed such places of refuge. It was similar with the poverty of southern Italy, the worker's culture assumed by the clearly Stalinist communist party, and the young male prostitutes of the subborgios. The race finally came to a halt in the »Orient.«In other words, he reenacted the flight of a Gauguin or a Murnau, but connected it to an explicit political agenda when he looked at these exotic places of paradise and saw a concrete potential for resistance against the dominance of the international culture of consumerism. While the aforementioned early Romantic and late Romantic artists depicted their exotic paradises from the start in non-naturalistic and purely painterly terms, Pasolini tried to retain the authenticity of the world as something quasi-»holy« through the pre-rational and unconventional »authenticity« of cinematic images. At the same time, if the myth of the innocent body was the only thing that promised resistance to the anthropological revolution he'd identified, then the political utopia of sexuality joins the concreteness of the film medium.

In the reality of his actual life, of course, he was able to obtain no more than vestiges of these primeval, resistant sites of his utopia, but they were enough for him to weave a blend of erotic stories from the »Orient« that are both oddly dreamlike and very real. While he still maintained the political assertion that this world resisted the grasp of expansive capitalism, in reality the artist fled not only into the exotic distance, but also into the realm of the fairytale.

All the same, in 1974, in Il Fiore delle Mille e Una Notte (Arabian Nights), literally »The Flower of One Thousand and One Nights, « he can still present the elabo- 
rate material in documentary form; in other words, he does not need to create it synthetically, like the fallen Renaissance cultures in Boccaccio's Il Decamerone (1970 and ' 7 I) or Chaucer's I racconti di Canterbury. The artfully symmetrical structure of the whole, comprised of numerous interlocking episodes, stands in strong contrast to the director's »cinéma vérité« in other films of his, which he shot on original sites with carefully selected individuals on extensive journeys to Ethiopia, Yemen, Iran, and Nepal..$^{36}$ A unique reinterpretation of realistic stylistic means ensues when these more or less record an earlier aestheticism of a magnificent »Orient, « which, as the director himself discovers, is indebted more to »oriental« miniatures than the reality of the $20^{\text {th }}$ century (Fig. 6.). Although it is only a selection of classical stories from the extensive collection of fairytales, the film takes the work's structure seriously. In contrast to the many Hollywood adaptations, all of which use the »oriental« decor as a mere backdrop for their very American stories, Pasolini addresses the intricate structure of the original to the point of the illegibility of its individual levels in order to be similarly interrupted by poems, recited in verse, that transform even the most direct description of sexual intercourse into pure poetry. In the weave of this tapestry, the staged parts merge easily with the architectures and landscapes of the various countries of Africa and Asia. It's about a reality of a myth that aims not at the representation of actual conditions, but at the authenticity of concrete objects, people, and buildings, whose authenticity alone can promise a successful resistance to the totalitarianism of a consumerist world that is becoming international (Fig.7).

Despite the considerable contrast between the austerity and severity of the Passion film and the colorful opulence and abundant sensuousness of the 
tales of Scheherazade, the worlds in each of these films are connected by the very »holy integrity « that capitalism ruthlessly destroys. To find this sacrality, to preserve it — as Kracauer says, to »save it« — is the film's loftiest possibility and political task.

This occurs against the backdrop of an awareness of the reality of the same »Orient « that has long since become part of a globalized dynamic that robs it of its own past. To reiterate, Pasolini is not a naïve romantic, but rather a passionate seeker of a reality that is contradictory and often cruel and ugly. It's a search he prepares for in another »notes film « about a journey to India he undertook with Alberto Moravia, a film in which the »old India of the gods and saints « is juxtaposed with Nehru's new nation and the struggles of the communist party. ${ }^{37}$ These are layers that can barely be brought together. As a result, we recognize the theme of the ultimately Eurocentric gaze of the aestheticist to which Pasolini already alluded in his 1969 cinematic »notes on Edipo Re, a film that documents the search for the authentic protagonists of an African Oresteia in contemporary Africa. ${ }^{3}$ The »notes« show Pasolini in a cinema questioning African students of the University of Rome on excerpts of the material as well as sections already staged that were set to appear in the finished film. Along with their statements, some of which were critical, it's chiefly the ambivalence of the situation, presented on film, that demonstrates the asymmetry of perspectives, for the people invited to take part in the discussion, members of a new post-colonial elite, must have recognized themselves, if not as persons, then certainly as part of a mythical categorization, a constellation in which it's only the artist-author Pasolini who is afforded real sovereignty. Here, too, the mode of aesthetic argumen- 


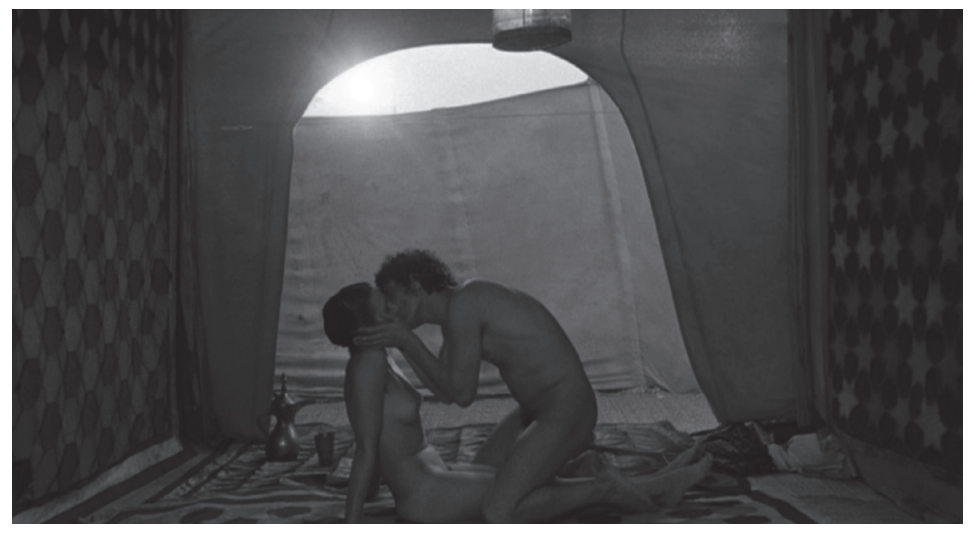

[FIG. 6]

Pier Paolo Pasolini (dir.): Fiori or erotic miniatures from the »Orient« in Il Fiore delle Mille e Una Notte, 1974

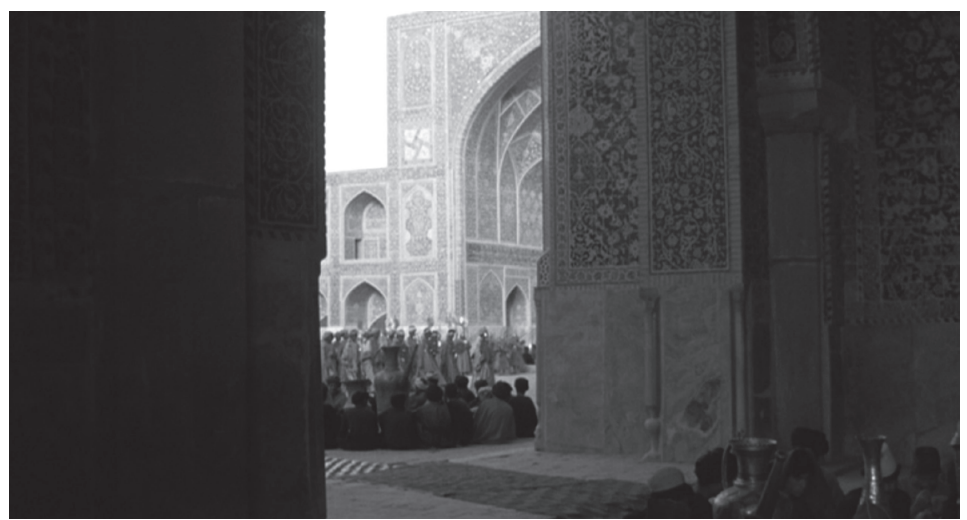

[FIG. 7]

Pier Paolo Pasolini (dir.): The romantic reality of Persian architecture in Il Fiore delle Mille e Una Notte, 1974 
tation is more a break or a juxtaposition of contradictions than a case of Pasolini opening up a rigorous historical perspective.

Thus, his deep rooting in the art of aestheticism becomes visible. In this regard, the only element connecting the ascetic invocation of a holy pimp in Accattone and the celebration of »oriental« love in Il Fiore delle Mille e Una Notte is the unifying factor of extreme artistic stylization, an aestheticism that seems to ridicule Pasolini's aesthetic of a direct »authentic « realism of a »cinematographic language of life. «39 While Pasolini was often enough discussed only in terms of the contradictions between his political allegiance to communism and the conservative cultural criticism of his mythical anthropology, critics frequently forget that Rimbaud served as a role model at the beginning of the young poet's career; the poet's phonetic experiments sharpened Pasolini's awareness of the physical impression made by his native Friulian tongue. With the fascist-led dictum of high Italian, the dialect was repressed, along with the special culture it represented. To Pasolini's mind, this dialect was similar to his efforts to retain the sensuousness of the body, which was no less threatened by consumerism. Beyond all claims to the contrary, beauty was the only political utopia that remained to the artist, who had also lost his home in the left. The film's formal mastery consists in the extreme aestheticization of reality itself. Similar to his literary preferences for French aestheticism of the $19^{\text {th }}$ century, this is an unmistakable sign that any original trust in the "state of reality, « any utopian hope in it has been lost, because it now justifies itself solely through its aesthetic appearance. What remains is a radical aestheticism whose »holy site is represented by the work of art alone. ${ }^{4}$

Thus, Pasolini — whose homelessness is evident in all the native habitats he invokes, and whose person has been practically spit out by them, when one 
recalls the circumstances of his exclusion from the communist party - is above all a poet. The only elements that form a continuity in this discontinuous life are his verse, words, critiques, films, and images. This perspective also explains the stylistic height with which the young poet already sought to raise the subcultural dialect of his native region of Friuli to the same literary level as the verses of his revered master Rimbaud or the »oriental« poetry of the fairytales of One Thousand and One Nights. It is the pure beauty capable of reconciling more or less all contradictions and making them bearable.

\section{The Orthodoxy of the Avant-Garde}

Yet this utopia of the myth of the body also collapsed under the realities of the consumerist present, upon which Pasolini also slandered this »last sanctuary.«In the end, he was forced to admit the failure of potential utopias crafted from the happiness of other cultures, only to admit — disgusted by the slickness and uniformity of Italian bodies — to the failure of his own films. ${ }^{41}$ Two years after the Trilogy of Life, he renounced his own »celebration of life, « because »the reality of the innocent bodies was (now also) injured, manipulated, and destroyed through the power of consumerism. « ${ }^{42}$ Thus his monumental last work, Salò o le I2O Giornate di Sodoma of 1975, is chiefly a discourse on the relationship between body, beauty, art, and fascism in which the brutality of the beautiful appearance vs. the aims of the humane is carried to the extreme. ${ }^{43}$

Hans Ulrich Reck described the film as a reaction to the disappointments over the Trilogy of Life: »Now, Eros is nothing more than trauma, bound to Thanatos, 
the death instinct that devours all. Eros occupies nothing more than the in-between states. $\ll^{44}$ The film ends with cruel scenes of torture. People are skinned alive and quartered. The disturbing vivisection is particularly unbearable because Pasolini mercilessly draws the viewer, as the center of obscenity and a mediaestablished lie, into the cinematographic apparatus and integrates him in his overriding critique of the murderous logic of all capitalist apparatuses. The viewer assumes the perspective of the eyes of the young men perversely enjoying the torture scenes in tango tempo, looking through the window into the courtyard of death.

The film culminates in a narrow pan to the viewer's own eye, which is reduced to the monocular eye of the camera and thus becomes an accomplice in a passive participation in the terror, basically the enabler of the murderous scenes. The violent ethos of voyeurism has never been more painfully, cuttingly staged. In his Abiura dalla Trilogia della Vita, written during the shooting of Salo, Pasolini said he was making a cruel film, so deathly cruel that he himself didn't yet know how to maintain or regain distance to it. From this point on, the story of this film entered into a fatal connection with the story of the end of his own life. He couldn't say what he was trying to express with Salò. He didn't know yet. The only thing clear to him was that it was about the »renunciation of sexual language altogether as such, in an absolute sense. «45 The victims, completely at the mercy of the sadists' gazes set in scene by the whores in daily meetings, no longer have a language (even of the body) and, as beautiful bodies, are no more than objects of pure lust.

The failure of the utopia of the body signified the end of Pasolini's political and artistic utopias. He now vilified the consensus of the avant-garde itself. 
His aestheticism, based on the artistic concepts of a radical modernism that was at all times ready to subject real life happiness to art's demands, had lost its innocence once and for all. The aestheticist made his radical break with his absolute belief in form, which meant disappointment in his own (modern) artistic activity. Pure beauty, the aesthetics of Décadence far from the morals that he'd once celebrated in the novel Ragazzi di Vita, had long since become the most terrible of truths for him. Now, the real orthodoxy emerges that his »heresies« are aimed at, namely modernism itself. He places the libertines, nihilism, and existentialism, in short, all the positions that broke completely with tradition, on the same level as fascism when he transfers the fantasies of the Marquis de Sade in the I2० Days of Sodom into the reality of the »Republic of Salò. «It's a total, absolute break with all morality through the powers of the old order, the judge, bishop, banker, and duke who are also representatives of the new, which is fascism.

And these gentlemen like to interrupt their "games « with scholarly discussions bolstered with quotes from the pertinent modernist de Sade literature on the total abolition of morality, i.e., with sentences by Roland Barthes, Maurice Blanchot, Simone de Beauvoir, Pierre Klossowski, and Philippe Sollers. The avant-garde had subordinated itself to a totalitarian system more than once, one that now found its latest and most subtle form in the consumerist society of the postwar era. ${ }^{46}$ Thus, the Marquis' stories are playced not only in the context of the historical fascism of northern Italy, but also in an abstract realm of modernist thought. While Visconti's German Trilogy connected the aestheticizing lust for total beauty with the disappearance of the gaze, this now switches to the brutal pornography of the torture scenes observed through the binoculars (Fig. 8). And if the barings in Il Fiore, which seem so permissive on the surface, 


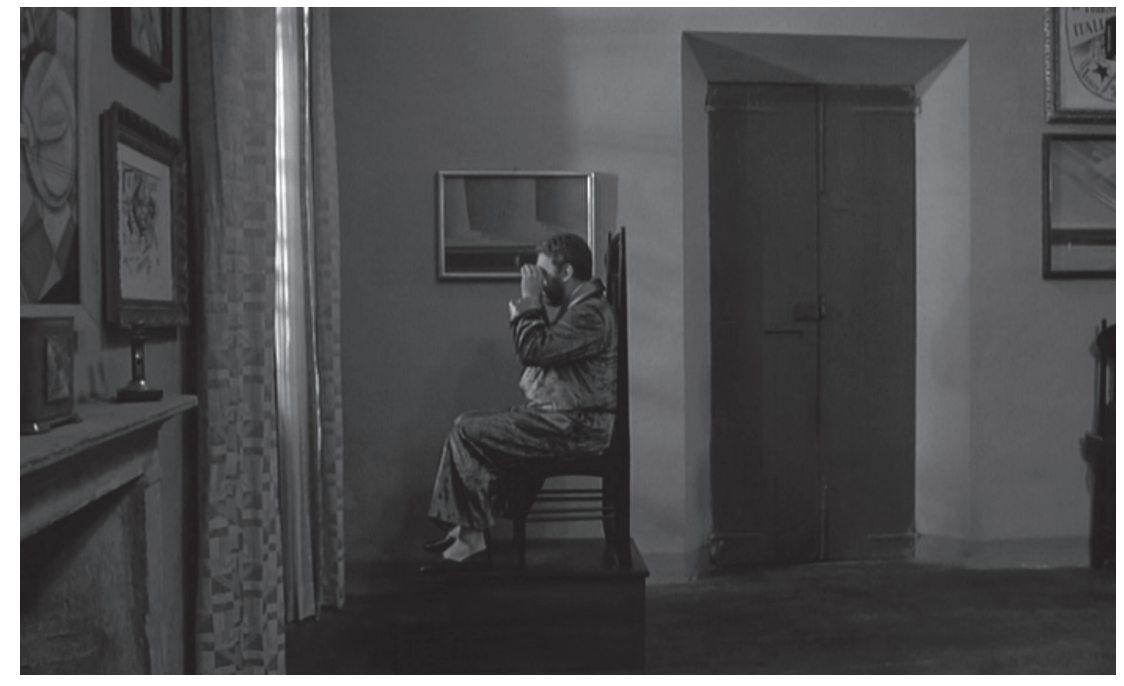

[FIG. 8]

Salò: A Gentleman with binoculars and modern art in Salò o le I2O Giornate di Sodoma, 1975

are ultimately brought to a head through the film's contextualization in the austere beauty of traditional »oriental« patterns of imagery and narration, the defenseless bodies in the hellish circles of blood and excrement are completely at the mercy of the perspective of voyeurism not only on the part of the film's protagonists, but also the viewers themselves. All the orthodoxies of religion, myth, and body that Pasolini had previously worshipped appeared here once again in an all-devouring inferno. More than anything, it is the aesthetic - and thus the aestheticist Pasolini himself — whose discourses are brought to their end: hence, it is modernism's most radical self-enlightenment.

Particularly in Germany, Pasolini was reproached again and again for hanging modernist paintings by Léger, Duchamp, and Severini et al. among the art deco work on the walls of the »ruling lords, « because this was the art of the vic- 
tims. Yet this art is also the expression of a cult of totalitarian form, an abstract exaggeration of concrete life that is literally perverted, in other words inverted, as a sign of complete negativity. ${ }^{47}$ The libertines are, then, the dogmatists of the church of consumerist society, which Pasolini counters with his heresies. Pasolini's desperate self-reckoning also requires the self-denunciation of the heretic. At any rate, the film was a classic scandal, as Wolfram Schütte described it in 1977 , right from the fray of left-leaning liberal self-assuredness: »It's said that Pasolini worked on the film until shortly before he was murdered, that he undertook some cuts himself and declared that he was afraid of Salo. The film premiered at the ist Paris Film Festival after ample publicity. Various Italian directors made the trip (such as Bernardo Bertolucci and Liliana Cavani); others (such as Antonioni, Rosi, and Visconti) sent telegrams to protest the film's complete censorship that had meanwhile been imposed in Italy. When at the end of January 1976 [...] Salò had its widespread debut in West German cinemas in an $\mathrm{FSK}^{48}$-approved edit - the distribution company had anticipated a commercial sequel in the style of Ultimo Tango a Parigi (Bertolucci) — it was confiscated here and there by state prosecutors but re-released in Frankfurt until the district attorney's office of Saarbrücken confiscated it across the country following an article in the Frankfurter Allgemeine Zeitung by Karl Korn, which could not be understood as anything but an unveiled call to censor the film across the board. $\ll^{49}$ From the 1980 s on, however, it reached audiences initially through important Pasolini events and subsequently on video and DVD. Today it is available without restriction. ${ }^{50}$

Schütte quoted some of the conservative critics, for example in an article in the FAZ on June 2, 1976 titled The Limits of Representation: »This is where the 
reporter seems to have reached a boundary, where to this day and for every society the protective taboo demands its rights. It is held in contempt here, it does not exist.< Or: >It must be said that Pasolini has in many ways gone beyond what society deems acceptable. The film infringes on the rights of society and the individual to be protected. What it offers with its third circle of Hell [...] in the way of excesses of cruelty can be taken for a temptation to brutality. [...] If the so-called voluntary self-control of the film industry, nearly forgotten in the public consciousness, had not degenerated to a farce [!] following the withdrawal of Church authority, one might ask the gentlemen if they've deleted from their minds the paragraphs calling upon them not to allow the glorification of violence in film. [...] Anyone who puts a so-called work of art on the public market that uncontestedly breaks with the most serious of taboos has to respect boundaries that the general understanding of norms sets [...]. Who protects the many thousands who see such a film without having been informed about its background and context? Who protects them from the psychological damage it can do? An explanation is essential.< The only thing that needs to be added to the margins of this flawless censorship prose in the way of information is that we also know of a critique of the film Jud Süß by the very same author, published in the noble Nazi newspaper Das Reich. «I

As justified as Schütte's indignation was, in 2016 such accusations seem more touching than anything else, given the predominance of sex and violence in both private and public broadcasting, video stores, and the Internet in the face of a contemporary neoliberal conservatism that has become reflexive. Pasolini's cultural pessimism predicted the dissolution of the traditional culturally conservative right into a hedonist consensus for which 
bodies and violence would become consumable, a culture to which any Tarantino film or first-person shooter video game can easily testify. In the final analysis, Fifty Shades of Grey offers a variation for the most general level of cultural acceptance. The libertinism as provocation of a Bunuel or a Dalí has long since been overtaken by everyday media; at the most, it can provide catchwords for media stimuli. The avantgarde as court jester has long become part of a system that reproduces itself through the production of its aberrations. In Salo o le I2O Giornate di Sodoma, this very modernist discourse becomes itself a theme, while the popes of the new dogmas have been left mercilessly to the unacknowledged consequences of their teachings. The real heresy of Pasolini, then, does not consist in provoking within the system of modernism and thereby assuming a position that in the end only leads to more and more integrations into modernism. Instead, Pasolini maligns the orthodoxy of modernism itself, in other words, heresy as an ultra-modern art program.

Pasolini was thus the heretic of an unarticulated consensus of modernism whose failure he had nothing more to counter with than his last heresy in Salò, a heresy of the human that has lost every utopian appearance. What is lost is the naivve certainty with which, four decades earlier, the young Surrealists Buñuel and Dalí believed they could serve an undetermined progress by breaking all taboos. It is almost an irony of fate that the severe conservative criticism that prevailed in the form of a long-term ban might have felt closer to the provocateur Pasolini than the praise of his admirers from the liberal art scene, whose modernist certainties he repeatedly shattered, as much as he himself was their product. There is, indeed, hardly any other film that questions its own preconditions to such a degree, to the point that see- 
ing, the cinematic gaze itself, is denounced. It is the same Pasolini whose camera once »sanctified « the material concrete world for which the cinematic signs were the »language of reality « who now allows us, as the movie-going public, to gaze through the binoculars with the perpetrators to watch the last execution of the victims at the end of Salò. He slanders the church most his own, that of cinematography.

As an aside, it should be said that one should beware of the film's stylization as the final statement prior to what then became the »necessary« death of the artist, for the utopias invoked by the works do not form a logical chain of models laid out one after the next, but always stand both for and against one another. ${ }^{52}$ This also applies to their total negation, because Salò does not depict a historical event, but the conditio humana. In an aesthetic sense, this position was only credibly possible as a process-based invocation and escape

1 Quote from an intertitle of the film, freely translated to English (translator's note). Salvador Dalí: L'Âge d'Or, 1930 .

2 Ibid.: Quote from an intertitle of the film. Freely translated to English (TN).

3 This motif continues throughout nearly the entire biography of the director. Luis Buñuel and Jean-Claude Carrière: Mon dernier soupir, Paris 1982 (My Last Sigh, Minnesota 2003).

4 The type of legal verdict imposed on the Viennese ac- tionist confirms this, in that the reason for the conviction was not the art, but the actual criminal offense, in other words, the principle of »art's freedom « was not applied here.

5 Thus the 1999 work by Maurizio Cattelan presenting a true-to-life figure of Pope Saint John Paul II, struck by a meteor and lying on the floor of an exhibition in the Kunsthalle Basel.

6 For an introduction, see Hans Ulrich Reck: Pier Paolo Pasolini - Poetisch-Philosophisches Portrait, Audio CD (Audiobook-Verlag), 2012. 
7 Pier Paolo Pasolini: Empirismo eretico è una raccolta di saggi scritta da Pier Paolo Pasolini, Milan 1972.

8 Pier Paolo Pasolini: Heretical Empiricism, Washington, DC 2005 . I quote the publication because of its title. In terms of this text, the collected essays of Pasolini published under the title Corsair Writings play a more prominent role. Pier Paolo Pasolini: Corsair Writings, (Scritti Corsari), Milan 1975 .

9 Freely translated to English (TN).

${ }^{10}$ Enzo Siciliano in particular explored Rimbaud's importance for Pasolini. Enzo Siciliano: Vita di Pasolini, Milan 2005 (New York 1982).

11 Terms such as heresy and slander are deliberately used as synonyms because a theological-philological explication of their usage in Pasolini's heterogeneous writings would be inappropriate.

12 The distinction is used in the sense of Eliade's classic and aesthetically influential differentiation, and not in terms of modern cultural anthropology. Mircea Eliade: The Sacred and the Profane. The Nature of Religion, New York 1959.

13 In Wolfram Schütte: Kommentierte Filmografie, in Pier Paolo Pasolini, ed. by Peter W. Jansen and Wolfram Schütte, Film Hanser series, vol. I2, Munich and Vienna 1977 , p. 122 .

${ }^{14}$ Cf. texts by Hans W. Ohly: Herbert Reich, and the French press, in Atlas Film's press sheet of 1965; as well as Uwe Nettelbeck in Die Zeit, (May 21, 1965); Herbert Linder in Filmkritik, 6 (1965), pp. 329 ff. Freely translated into English (TN).
15 Quoted from Oswald Stack: Pasolini on Pasolini, London 1969, pp. $87 \mathrm{ff}$.

${ }^{16}$ Particularly significant here is Pasolini's employment of his friends (some of them sexual), e.g. Ninetto Davoli and Giorgio Agamben, and particularly his casting of his mother, Susanna Pasolini, as the old Maria. We know the problems of the early modern donor figures, but here it is more a matter of the old motif of then Imitatio Christi by atheists.

17 Stack: Pasolini on Pasolini (see note I5), p. 83.

${ }^{18}$ Schütte: Kommentierte Filmografie(see note i3), p. I2 4 f.

19 Pasolini also documented this cinematographically in a kind of 52 -minute-long »Note film «- a format typical of the time: Sopralluoghi [literally »on-site visit«] in Israel/Palestine for il Vangelo secondo Matteo, Italy 1963 64, director and commentary: Pier Paolo Pasolini, music selected by Pier Paolo Pasolini. Film sites included the Sea of Galilee, Mount Tabor, Nazareth, Capernaum, Jordan, Jerusalem, Bethlehem, Sinai, and Damascus.

${ }^{20}$ Cf. Pasolini in Schütte: Kommentierte Filmografie (see note 13), p. 60 f.

${ }^{21}$ Pasolini: Das r. Evangelium - Matthäus. Arthaus DVD, Kinowelt Home Entertainment 2004 (Production Notes under Extras). Freely translated to English (TN).

${ }^{22}$ More on "authenticity as an aesthetic strategy" in Norbert M. Schmitz: Der Diskurs über Performance und der Mythos des Authentischen. Eine Kunstform als Übung zivilisatorischer Alltagsästhetik, in Petra Maria Meyer (ed.): Performance im medialen Wandel, Munich 2006, pp. 441-462. 
23

Pasolini studied with Roberto Longhi in Bologna.

${ }^{24}$ For an overview, see Maurice Tuchman / Judi Freeman (eds.): Das Geistige in der Kunst - Abstrakte Malerei I895-1985, Stuttgart 1988; more critical: Beat Wyss: Die Kunst aufder Suche nach ihrem Text, in Maurice Tuchman/Judi Freeman (eds.): Mythologie der Aufklärung

- Geheimlehren der Moderne, Munich 1993; Norbert M. Schmitz: Kunst und Wissenschaft im Zeichen der Moderne, Alfter bei Bonn 1993, Pp. 325-418.

${ }^{25}$ On the relationship between film and Catholic pictorial rhetoric, see Norbert M. Schmitz: Eisensteins Bildrhetorik. Die Konstruktion der Tradition, in Michael Neumann (ed.): Anblick/Augenblick, Wurzburg 2005 , pp. $173^{-189}$.

${ }^{26}$ Pasolini himself addressed the particular cynicism of such biblical films in Pier Paolo Pasolini (dir.): La Ricotta, 1963 .

${ }^{27}$ In a certain sense, Pasolini's novel Il sogno di una cosa of 1962 inverts the original intention of Marxist thinking. While Marx was interested in exposing the progressive political content behind the myths, Pasolini believed he would finally find the real utopia in them. Cf. Peter Kammerer: Der Traum vom Volk, in Schütte: Kommentierte Filmografie (see note 13), pp. 13-34.

${ }^{28}$ Hans Ulrich Reck: Pier Paolo Pasolini, Munich 2010, p. 47. Freely translated to English (TN).

29 As romantic as this cultural criticism might sound, it also includes topoi of the scientific discourses of the time; Pasolini's historical model, for instance, can easily be interpreted as a »dialectic of enlightenment.« Max Horkheimer / Theodor W. Adorno: Dialectic of Enlightenment: Philosophical Fragments, Stanford/
CA 2002.

${ }^{30}$ Pier Paolo Pasolini: A Study on the Anthropological Revolution in Italy, trans. Juliana Schiesari, in Beverly Allen (ed.): The Poetics of Heresy, Saratoga, CA 1982 , Pp. II3-II 4 .

${ }^{31}$ Cf. Peter Kammerer, in Schütte: Kommentierte Filmografie (see note 13 ), PP. ${ }^{3} 3-34$.

${ }^{32}$ Were it not for space restrictions, this argument could be further expanded through films such as Edipo Re, Medea, and the project of an »African Oresteia.« Cf. Reck: Pasolini (see note 28), p. 51-52.

${ }^{33}$ In this respect, Pasolini remains contradictory, also in terms of his own homosexual desire, because he disregards the libertinage in his own life to which he unconditionally submits.

${ }^{34}$ In more detail cf. Hans-Edwin Friedrich / Hans J. Wulff (eds.): Pasolinis Filmanthropologie - Die Schrift des Lebens, in Scriptura cinematographica: Texttheorie der Schrift in audiovisuellen Medien (Filmgeschichte International. Schriftenreihe der Cinémathèque de la Ville de Luxembourg, 21) Triere 20I3, Pp. 203-224. The following chapter on »bodies « is closely based on this text.

${ }^{35}$ In 1963, Pasolini addresses this cultural shift as a cinematographic essay in the interview and discussion documentation Comizid'amore.

${ }^{36}$ There is a gap between the native characteristics of the many faces from a broad cross-section of peoples and cultures and the naked bodies of the main actors, almost all of whom were Italian. Pasolini, who otherwise tended to emphasize multiplicity, was unable to fully 
break with the conventions of international cinema.

37 Pasolini's Appuntiper un film sull'India of 1968 can easily be seen as a »notes film $\ll$ for the later Il Fiore.

${ }^{38}$ Appuntiper un'Orestiade africana of 1970.

39 On the distinction between realistic stylistics (also in cinema), cf. Stephan Kohl: Realismus - Theorie und Geschichte, Munich 1977.

${ }^{40}$ Similarly, concerning the difference of language and image in Pasolini's work, Reck remarked that "particularly for Pasolini, one may assume an overarching unity of the poetic that can be termed lyrical or cinematopoetic."Freely translated to English (TN). Hans U1rich Reck: Film, Kunst, Kino. Die >Kunst des Films aus der Sicht und als Chance der Kunstgeschichte, in Thomas Hensel / Klaus Krüger/Tanja Michalski (eds.): Das bewegte Bild. Film als Kunst, Munich 2006, P. I2I.

41 This notwithstanding the fact that it was in any case only the third film of the trilogy, Il Fiore, that Pasolini completed and that did not remain unfinished. Cf. Schütte: Kommentierte Filmografie (see note 13), pp. I7O and 173 .

42 Pier Paolo Pasolini, in Corriere della Sera (Nov. 9, 1975). Freely translated to English (TN).

${ }^{43}$ While Visconti, in his German Trilogy, still speaks of fascism's affinity for the beautiful, to Pasolini's mind, its true core is pure aestheticism beyond morality.

${ }^{44}$ The reference here is to a text presented as a monologue - an »autointervista« titled Abiura dalla Trilogia della vita, in Laura Betti / Michele Gulinucci (eds.): Le regole di un' illusione. I film, il cinema, Rome 1991, pp. 315 ff.
${ }^{45}$ Reck: Pasolini (see note 28 ), p. 54.

${ }^{46}$ More than the polemics in question might lead one to assume, this clearly connects him to the discourses of the '68 revolutionaries and hippies. Cf. Herbert Marcuse: One-Dimensional Man. Studies in the Ideology of Advanced Industrial Society, Boston 1964 .

${ }^{47}$ Pasolini, however, says that the castle should resemble an »Italian Bauhaus « that was »confiscated from a wealthy deported Jew.«It's precisely here, though, that the short circuit between perpetrator and victim becomes visible, in a modern era that became an expression of a post-ideological, post-moral consumerist reality independent of the »superficiality of style."

${ }^{48}$ German organization for the voluntary rating system of the film industry.

${ }^{49}$ Schütte: Kommentierte Filmografie (see note I3), p. I7 8.

${ }^{50}$ Reck: Pasolini (see note 28 ), p. 55.

${ }^{51}$ Schütte: Kommentierte Filmografie (see note 13), p. 195.

52 On speculations concerning Pasolini's death, some of which are abstrusely esoteric, see Bernhart Schwenk/ Michael Semff(eds.): P.P.P. Pier Paolo Pasolini, cat. on the exhib. at Pinakothek der Moderne, Munich, Nov. 17,/2005-Feb. 5, 2006, Ostfildern-Ruit 2005. On the other hand, Reck confidently lists the many projects Pasolini still strove to accomplish at the time. Reck: Pasolini (see note 28), p. 55-56. 